Review Article

\title{
Congenital Pulmonary vein stenosis - Diagnosis and treatment.
}

\author{
Navaneetha Sasikumar ${ }^{1}$, Indra $\quad$ Kuladhipati $^{2}$, Sowmya $\quad \operatorname{Ramanan}^{3}$, Premsekar $\quad$ Rajasekaran $^{4}, \operatorname{Raghavan}^{2}$ \\ Suramanyan $^{5}$, Krishna Manohar Soman Rema ${ }^{6}$
}

${ }^{1}$ Navaneetha Sasikumar, MD, DM, ${ }^{2}$ Indra Kuladhipati, MD, DM, ${ }^{3}$ Sowmya Ramanan, MS, MCh, FRCS, ${ }^{4}$ Premsekar Rajasekaran, MRCP, ${ }^{5}$ Raghavan Suramanyan, MD, DM, ${ }^{6}$ Krishna Manohar Soman Rema, MS, MCh

1. Department of Pediatric Cardiology and Pediatric Cardiac Surgery, Frontier Lifeline Hospital, R-30C, Ambattur Industrial Estate Road, Mogappair, Chennai, India.

2. Department of Cardiology, Ayursundra Advanced Cardiac Centre, 3rd floor, 3rd building, Downtown Hospital Campus, GS Road, Dispur, Guwahati, Assam.

Address for Correspondence: Dr. Navaneetha Sasikumar, Email: drnavni@yahoo.com

\begin{abstract}
Congenital pulmonary vein stenosis is a rare and interesting condition. This disease was classically believed to have an exceptionally bad prognosis. This article reviews the pathophysiology of the disease and advancements in diagnosis and management.
\end{abstract}

Keywords: Congenital heart disease; Pulmonary veins, abnormalities; Pulmonary veins, physiopathology; Pulmonary veins, surgery.

\section{Introduction}

Congenital pulmonary vein stenosis is an interesting condition which is probably under diagnosed and is exceptionally difficult to manage. In spite of advances in surgical and catheter based management of this disease, prognosis remains at the best guarded in a significant proportion of the patients.

This article reviews the aetiology diagnostic methods and advancements in treatment.

\section{Incidence}

Congenital pulmonary vein stenosis is deemed to be a rare anomaly. Its reported prevalence is 1.7 per $1,00,000$ children less than two years old [1]. The very fact that it has been reported in $0.5 \%$ of autopsy cases suggests that there is possibility of under diagnosis [2].

Associated cardiac defects have been reported in $30-80 \%$ of patients, most commonly septal defects [3]. It is interesting and important to note that the largest surgical series of congenital pulmonary vein stenosis reports 23 patients, among which there was no case of isolated pulmonary vein stenosis [4]. Among the patients who succumbed to the disease in this series, 9 out of $11(81.81 \%)$ had septal defects or a patent ductus arteriosus as associated defects. This emphasises the importance of congenital pulmonary vein stenosis in the prognostication of otherwise simplecardiac defects.

\section{Etiology and Patho-physiology}

Abnormal incorporation of the common pulmonary vein into left atrium during the later stages of its development leads to congenital pulmonary vein stenosis [5]. However, there is increasing recognition of an underlying neoproliferative process caused by myofibroblastic cells leading to rapid progression of disease which might not even be evident at birth $[6,7]$.

This has reportedly led to a preference for the term primary over congenital [3]. 
Figure: 1 and Figure: $\mathbf{2}$ show angiographic images of a patient with congenital pulmonary veinstenosiswho developed re-stenosis post surgical repair using the suture-less technique described later.

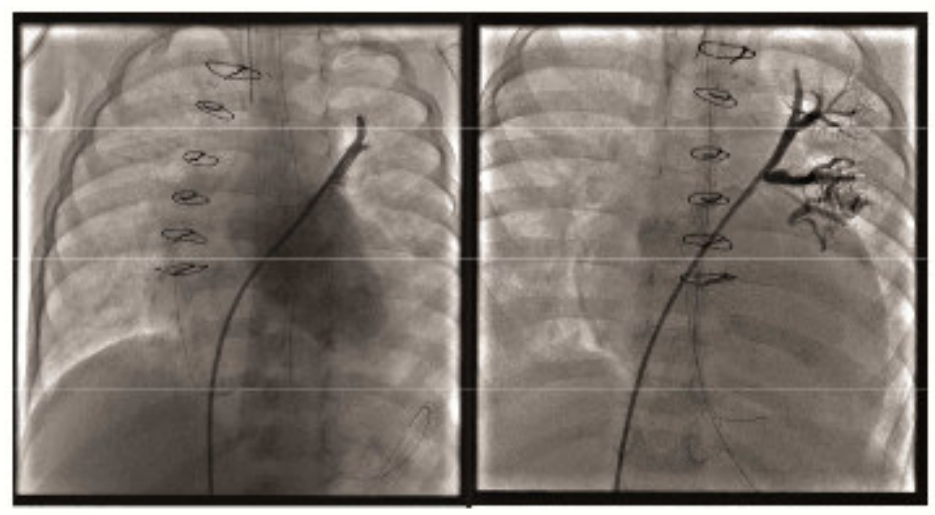

Figure 1 - Small sized, patent upper branch of left upper pulmonary vein at first catheterization study post surgery (left) and 1 month later (right) showing new areas of focal stenosis. Note that left atrium is less opacified in the right image with reflux of dye into distal and lower branches due to the proximal obstruction and 5French catheter almost occluding the mouth of pulmonary vein completely.

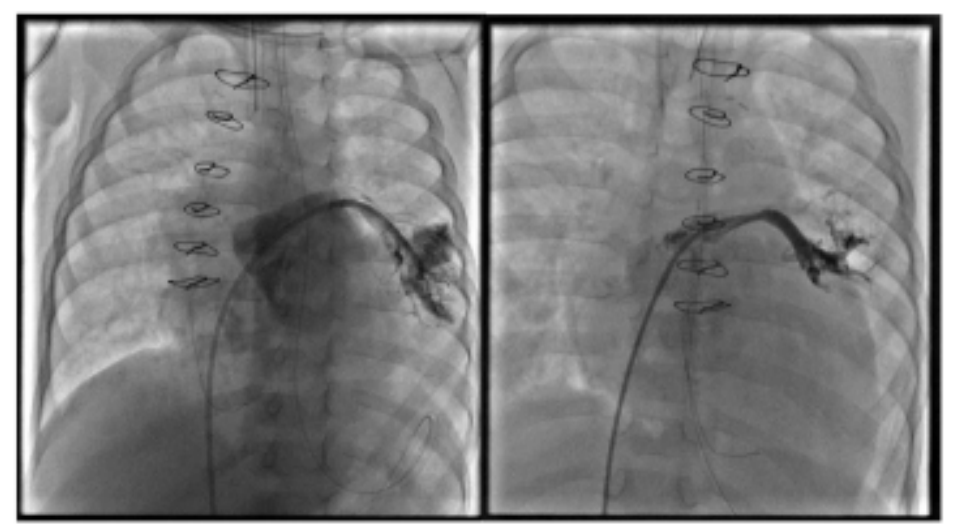

Figure 2 - Lower branch (lingular) of left upper pulmonary vein at first study post surgery

(left) and 1 month later (right) showing new focal stenosis.

The comparative images on the left and the right are from angiograms done at an interval of one month and shows rapid progression of disease. Stenosis may appear as a discrete shelf, a segment of narrowing extending from the mouth of the pulmonary vein for a short distance or a diffuse hypoplasia extending into the hilum/intrapulmonary segments [7,8]. Differentiating focal stenosis from diffuse hypoplasia is of extreme Importance as the latter has exceptionally worse prognosis [9]. Active inflammation has not been found in or around the affected veins [3].

The fixed obstruction in the pulmonary veins produces a secondary increase in pulmonary artery pressure and decreased pulmonary blood flow in the corresponding lung/lobes. In these lung/lobes, the elevated pressure causes vascular muscle to develop more peripherally than is normal and medial hypertrophy of arteries develops, as has been observed in other forms of pulmonary venous obstruction. The reduced flow leads to decreased arterial size. Any unobstructed lobe accommodates the diverted pulmonary blood flow and can lead to a functional stenosis of the anatomically unobstructed pulmonary vein. Arterial changes can be produced in the unobstructed lobes by the increased flow and the resulting increased pressure. The small- and medium-sized pulmonary veins show medial hypertrophy [9]. Insufficient drainage of blood from the affected lung leads to pulmonary congestion, recurring respiratory infections, and haemoptysis [10]. 


\section{Clinical presentation}

Controversy persists as to whether the number of pulmonary veins involved and the degree of obstruction affects the onset and severity of disease $[3,11]$. It seems plausible that progression of symptoms may be less rapid if only one or two pulmonary veins are involved [12]. Even in initially less severe cases, progression to bilateral pulmonary vascular disease and death has been described [5,7, 13-20].

The presentation is usually in the first months to years of life with history of significant respiratory symptoms. Patients may have recurrent pneumonia. They also have diffuse or localized pulmonary oedema depending on the anatomic involvement. Haemoptysis is prominent in older patients [3]. Features of pulmonary hypertension become evident later in the course as the disease progresses. The frequency of associated heart defects and reports of progression from normal pulmonary venous flow to progressive stenosis warrants evaluation of pulmonary veins during every echocardiographic study [21]. Also the pulmonary veins need to be critically looked at in any patient with unexplained pulmonary hypertension. Other diseases that can present similarly include most other causes of pulmonary venous hypertension including mitral atresia and different anatomical types of congenital mitral stenosis, cor triatriatum, tumour of the left atrium and total anomalous pulmonary venous connection with obstruction. Pulmonary venoocclusive disease, a close differential diagnosis is a poorly understood syndrome wherein there is extensive and diffuse occlusion of pulmonary venules and small veins by fibrous tissue. Larger veins are rarely involved in pulmonary venoocclusive disease [22].

Chest x-rays show a normal sized heart or cardiomegaly once the right heart gets involved. Characteristically, the pulmonary fields in pulmonary venous obstruction show a fine, reticulated vascular pattern, passive pulmonrary congestion, or frank pulmonary edema with distribution determined by the vein/veins involved. Features of pulmonary artery hypertension appear later.

Electrocardiograms show right ventricular and right atrial enlargement [8]. Secondary pulmonary vein stenosis is seen in pediatric patients most commonly after surgery for total anomalous pulmonary venous connection [3]. Other causes include invasion by tumour tissue, mediastinitis, constrictive pericarditis and pulmonary vein phlebitis as in tuberculosis $[8]$.
Primary pulmonary vein stenosis, similar to that in children has been rarely reported in adults. Of late, the commonestcause of secondary pulmonary vein stenosis in adults has been radiofrequency ablation for treatment of atrial fibrillation [23,24]. Sarcoidosis has also been described as a cause for secondary pulmonary vein stenosis in adults, in addition to the causes mentioned for children.

\section{Diagnosis}

Echocardiography is the primary modality of diagnosis and is usually adequate especially in children with good acoustic windows. 2D evaluation of the size and Doppler interrogation of individual pulmonary veins are done. Turbulent flow found during colour Doppler interrogation of pulmonary veins raises suspicion. A monophasic flow or flow velocities more than $1.6 \mathrm{~m} / \mathrm{s}$ indicates significant obstruction [26]. A pre-operative pulmonary vein stenosis score incorporating 2 Dimensional echocardiographic assessment and Doppler interrogation of the pulmonary veins has been proposed. This score is found to have excellent correlation with intraoperative and autopsy findings and is helpful in predicting mortality post surgery [4]. Echocardiography also helps in ruling out most of the other causes of pulmonary venous hypertension. Multidetector CT is an excellent tool for more detailed evaluation, especially for planning therapeutic strategies. An important concern with CT is its inability to differentiate completely occluded pulmonary veins from those with a tiny residual opening still adequate for catheter intervention [27]. CT might add information to exclude compression of extrapulmonary segments of pulmonary veins and also help in differentiating pulmonary venoocclusive disease. MRI has the advantage of avoiding ionising radiation, but has limitations of long acquisition times, sensitivity to motion artefacts and arrhythmias and limited spatial resolution [3].

Cardiac catheterisation study and angiography was the modality of choice for confirmatory diagnosis of congenital pulmonary vein stenosis before the era of advancement in noninvasive diagnostic techniques [5]. In the current era, invasive study is done mainly with the intention of percutaneous dilatation. The presence of pulmonary artery hypertension along with an elevated pulmonary capillary wedge pressure and a normal left atrial pressure suggests congenital obstruction of the extra pulmonary segments of the pulmonary veins [9]. 


\section{Review Article}

Selective angiograms can be done from arterial segments that drain to each of the pulmonary veins. Pulmonary artery segments draining into severely stenosed pulmonary veins may have little antegrade flow and the contrast may even flow backwards into arteries that drain less stenotic veins. Balloon wedge angiography from the segmental pulmonary artery is helpful in such situations and may even show patency missed by non invasive methods [3,27]. Alternately, direct visualization of non occluded pulmonary veins can be made entering the left atrium through an atrial septal defect/patent foramen ovale or via transeptal puncture if the atrial septum is intact. In pulmonary veno-occlusive disease, a close differential diagnosis, the characteristic finding described has been inability to obtain a pulmonary artery wedge tracing. If at all the catheter is wedged, the wedge pressure recording would be normal [22].Radionuclide quantitative pulmonary flow imaging identifies redistribution of flow in case of asymmetric pulmonary vein stenosis and is recommended before any intervention and for follow up.

\section{Treatment}

Untreated, long term survival is rare and the mode of death is a pulmonary hypertensive crisis, inter current infection or hemoptysis [3]. Early surgical techniques and catheter interventions were reported tohave dismal results . This was attributed to relent less re stenosis. A variety of techniques have been proposed for surgical repair ever since the first attempt by Kawashima and colleagues [28]. It was speculated that the patch material used in surgical venoplasty techniques acted as a substrate for turbulent blood flow triggering intimal hyperplasia. Trauma caused by direct suturing of the pulmonary vein intima was also believed to stimulate further injury response, accelerating restenosis. Lacour-Gayet et al first described a technique to avoid both these issues during surgical repair ${ }^{2}$. This technique, called the suture-less pulmonary vein repair (Figure 3) avoids stitches at the cut edges of the pulmonary veins and uses pedicled autologous pericardium for marsupialisation around the openings of pulmonary veins forming a neo atrium. This has better results in both congenital and acquired forms and is increasingly used in primary repair for pulmonary vein anomalies at high risk of post repair restenosis [3,30]. Mid to long term results of this technique are encouraging (Table - 1). The technique best suits anatomically localized disease, diffuse disease has been recognized as a technical challenge [31].

Figure 3 - The "suture-less" technique of repair for pulmonary vein stenosis. The figure shows the approach to right sided veins. The dotted line illustrates the line of excision of the narrow pulmonary veins along with left atrial wall if required. The dashed line illustrates the final suture line which would approximate the atrial wall with pericardium. The pulmonary veins will drain into the neoatrium thus created and then into the left atrium.

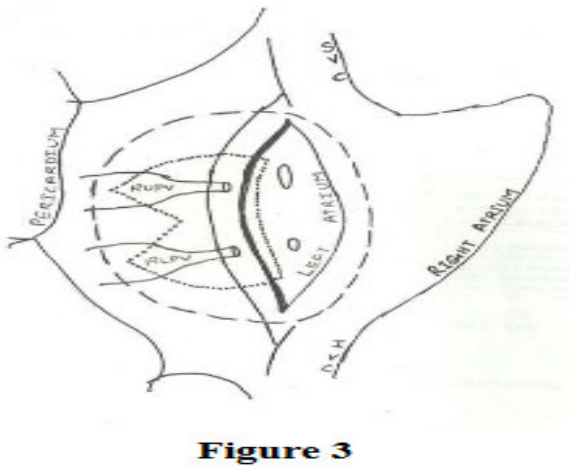

The ostium of the left lower pulmonary vein is also narrow as seen from within the left atrium. The left atrial appendage can also be used for marsupialization of the left sided veins.

Table-1 Results of the suture-less technique of pulmonary vein repair for congenital pulmonary vein stenosis

\begin{tabular}{|c|c|c|c|c|c|}
\hline Author & $\begin{array}{l}\text { Number of } \\
\text { patients }\end{array}$ & $\begin{array}{l}\text { Follow up } \\
\text { duration }\end{array}$ & $\begin{array}{l}\text { Freedom from re- } \\
\text { stenosis /death }\end{array}$ & Deaths & Comments \\
\hline $\begin{array}{l}\text { Devany et } \\
\text { al [20] }\end{array}$ & $\begin{array}{l}\text { Suture-less } \\
\text { in } 8 / 14\end{array}$ & $\begin{array}{l}25 \text { months } \\
\text { (median) }\end{array}$ & $50 \%($ suture-less $)$ & $\begin{array}{l}2 \text { early; 1 late (all } \\
\text { associated with re- } \\
\text { stenosis) }\end{array}$ & $\begin{array}{ll}\text { Bilaterality } & \text { predicts } \\
\text { diffuse disease } \& \text { poor } \\
\text { outcome }\end{array}$ \\
\hline $\begin{array}{l}\text { Azsakie et } \\
\text { al [30] }\end{array}$ & 7 & $\begin{array}{l}\text { 34months } \\
\text { (median) }\end{array}$ & $57 \%$ (suture-less) & $\begin{array}{l}1 \text { late death (during a } \\
\text { gen } \\
\text { procedure) }\end{array}$ & $\begin{array}{l}\text { Effective for discrete } \\
\text { stenosis; diffuse disease - } \\
\text { technical challenge }\end{array}$ \\
\hline $\begin{array}{l}\text { Nicola } \\
\text { Viola et al } \\
{[4]}\end{array}$ & $\begin{array}{l}\text { Suture-less } \\
\text { in } 19 / 23\end{array}$ & $\begin{array}{l}40.2+/-42.2 \\
\text { months } \\
\text { (mean +/- } \\
\text { SD) }\end{array}$ & $\begin{array}{l}64 \%-1 \mathrm{yr} \\
47 \%-5 \mathrm{yr} \\
31 \%-10 \mathrm{yr} \text { (overall) } \\
42 \% \text { mortality excluding } \\
\text { non suture-less repairs }\end{array}$ & $11-$ total deaths & $\begin{array}{l}\text { Preoperative pulmonary } \\
\text { vein stenosis score } \\
\text { predicts mortality }\end{array}$ \\
\hline
\end{tabular}


Review Article

Among the available treatment options for diffuse disease, bilateral sequential lung transplantation has good short term results. Mendel off et al reported three patients who underwent bilateral sequential lung transplantation. Average hospital stay was 42 days after transplantation [32]. One of these patients was on ECMO (extra corporeal membrane oxygenation) for 24 days before transplantation. There was no echo evidence of PAH on 0.5 to 1.8 years follow up. An analysis of the pediatric cardiac care consortium database identified younger age at diagnosis, higher initial mean pulmonary artery pressure and bilateral vessel involvement as predictors of lung death and recommended early considerartion of lung transplantation for these subsets [11]. Breinholt et al described two patients who underwent cardiac transplantation for other indications. Stenosed recipient pulmonary veins were not addressed during transplantation. Both patients were fine at six and 11 months post transplant [21]. As pulmonary pressures were in the range acceptable for heart transplant, these patients possibly had a milder form of disease. As diffuse disease is attributed to neoproliferative process, the possibility of use of antiproliferative drugs for prevention of re-stenosis after surgery or as treatment seems attractive. There have been anecdotal reports on use of oral steroids to prevent post operative pulmonary vein stenosis [33]. Antiproliferative drugs are another option. A prospective phase 2 trial of weekly vinblastine and methotrexate in children had only $38 \%$ survival at $1 \mathrm{yr}$ for patients with associated congenital heart disease. There were two patients with isolated disease, both of them died from progression [34]. Oral sirolimus has been successfully used for recurrent stenosis in adults [35]. Catheter interventions have acceptable immediate results with the disadvantage of recurrence; but can be used multiple times for temporary relief of focal stenoses. Repeat procedures can slow down the disease process [3]. High pressure balloon dilatations and cutting balloons give better results [3]. Overall; results of catheter intervention for pulmonary vein stenosis are better in adults compared to children as the larger lumen achieved decreases restenosis rates; lesser number of veins are involved and few patients have associated heart disease. Stenting has better results in adults compared to balloon angioplasty; literature is conflicting regarding the use of drug eluting stents [3,36]. Although initial reports were discouraging [12,37,38]; a variety of stents - bare-metal, drug eluting and covered were recently reported to have acceptable acute results in children for focal obstruction. Recurrence was more with smaller stents. Survival rate was $50 \pm 8 \%$ at 5 years after pulmonary vein stent implantation. Freedom from reintervention was $62 \pm 7 \%$ at 6 months and $42 \pm 7 \%$ at 1 year [38]. Cryo-balloon [39] and drug eluting balloon have acceptable acute results [40]. Intrastent sonotherapy reportedly has good result for re stenosis after stent implantation [41]. Challenges in children include diffuse disease, small size of diffusely narrowed veins and need for trans-septal puncture if there is no PFO.

\section{Summary}

Abnormal embryologic events, a neoproliferative process has been identified, which lends a progressive Congenital pulmonary vein stenosis is a rare disease. Although its origin is attributed to nature to the disease. Echocardiography is currently the primary modality of diagnosis and a high index of suspicion is required for identification of the disease process. Other non invasive modalities provide detailed information and are used mainly for planning catheter interventions. Surgical relief using the sutureless technique is the preferred treatment modality. Catheter interventions can be used repeatedly for re-stenosis. Encouraging results are being recently reported, repeat procedures can also slow down the disease process. A variety of investigational modalities have been applied to manage diffuse and repeated restenosis which can be tried before a decision is made for lung transplantation. The prognosis in certain subsets of patients remains grim in spite of advances in treatment. Larger studies using newer modalities of treatment would help to improve prognosis in the difficult to treat subsets.

\section{Disclosure}

The images shown in Figure 1 and 2 had been included in the paper "Our experience with the suture-less technique of repair for primary pulmonary vein stenosis" presented at the Annual Conference of the Pediatric Cardiac Society of India, held at Chennai, India in October 2012.

This paper was also accepted for the 6th World congress of Pediatric Cardiology and Cardiac Surgery, to be held at Cape Town, South Africa in February 2013.

\section{Funding: Nil}

\section{Conflict of interest: None}

Permission from IRB: Yes

\section{References}

1. Drossner DM, Kim DW, MaherKO, Mahle WT. Pulmonary vein stenosis: Prematurity and associated conditions. Pediatrics 2008; 122:e656-61. [PubMed]

2. Howels-Gurich H. Pulmonary veinstenosis. Orphanet Encyclopedia. March 2003.

3. Latson LA, Prieto LR. Congenital and acquired pulmonary vein stenosis. Circulation 2007;115:103-8.[PubMed]

4. Viola N, Alghamdi A A, Perrin D G, Wilson G J, Coles J G, Caldarone C A . Primary pulmonary vein stenosis: The impact of suture less repair on survival. J Thorac ardiovasc Surg 2011; 142:344-50. [PubMed]

Available online at: $\underline{w w w . i j m r r . i n}$ $24 \mid \mathrm{P}$ a g e 


\section{Review Article}

5. Edwards JE. Congenital stenosis of pulmonary veins: pathologic and developmental considerations. Lab Invest 1960; 9:46-66. [PubMed]

6. Sadr IM, Tan PE, Kieran MW, Jenkins KJ. Mechanism of pulmonary vein stenosis in infants with normally connected veins. Am J Cardiol 2000; 86:577-79. [PubMed]

7. Bini RM, Cleveland DC, Ceballos R, Bargeron LM, Pacifico AD, Kirklin JW. Congenital pulmonary vein stenosis. Am J Cardiol 1984; 54:369 -75. [PubMed]

8. Shone JD, Amplatz K, Anderson RC. Congenital stenosis of individual pulmonary veins. Circulation 1962;26:574-81. [PubMed]

9. Geggel RL, Fried R, Tuuri DT, Fyler DC, Reid LM. Congenital pulmonary vein stenosis: structural changes in a patient with normal pulmonary artery wedge pressure. J Am Coll Cardiol. 1984; 3:193-9. [PubMed]

10. Reid JM, Jamieson MP, Cowan MD. Unilateral pulmonary vein stenosis.Br Heart J 1986; 55: 599-60. [PubMed]

11. Holt DB, Moller JH, Larson S, Johnson MC. Primary pulmonary vein stenosis. Am J Cardiol 2007; 99:568-72. [PubMed]

12. Driscoll DJ, Hesslein PS, Mullins CE. Congenital stenosis of individual pulmonary veins: clinical spectrum and unsuccessful treatment by trans venous balloon dilation. Am J Cardiol 1982; 49:1767-72.

13. Van Son J AM, Danielson GK, Puga FJ, Edwards WD, Driscoll DJ. Repair of congenital and acquired pulmonary vein stenosis Ann Thorac Surg 1995; 60:144-50. [PubMed]

14. Reye D. Congenital stenosis of the pulmonary veins in their extrapulmonary course. Med J Austr 1951; 1:801-2. [PubMed]

15. Emslie-Smith D, Hill IGW, Lowe KG. Unilateral membranous pulmonary venous occlusion, pulmonary hypertension, and patent ductus arteriosus. $\mathrm{Br}$ Heart J 1955; 17:79-84.

16. Bernstein J, Nolke AC, Reed JO. Extra pulmonic stenosis of the pulmonary veins. Circulation 1959; 19:891-7. [PubMed]

17. Lucas R, Anderson R, Amplatz K, Adams P, Edwards J. Congenital causes of pulmonary venous obstruction. Pediatr Clin North Am 1963; 10:781-836. [PubMed]
18. Contis G, Fung RH, Vawter GF, Nadas AS. Stenosis and obstruction of the pulmonary veins associated with pulmonary artery hypertension. Am J Cardiol 1967; 20:71824. [PubMed]

19. Mortensson W, Lundstr6m NR. Congenital obstruction of the pulmonary veins at their atrial junctions. Review of the literature and a case report. Am Heart J 1974; 87:359-62. [PubMed]

20. Devaney EJ, Chang AC, Ohye RG, Bove EL. Management of Congenital and Acquired Pulmonary Vein Stenosis. Ann Thorac Surg 2006; 81:992-96. [PubMed]

21. Breinholt JP, Hawkins JA, Minich L, Tani LY, Orsmond GS, Ritter S, Shaddy RE. Pulmonary vein stenosis with normal connection: associated cardiac abnormalities and variable outcome. Ann Thorac Surg 1999; 68:164-68. [PubMed]

22. Mandel J, Mark EJ, Hales CA. Pulmonary Venoocclusive Disease. Am J Respir Crit Care Med 2000; 162:1964-73.

[PubMed]

23. Omasa M, Hasegawa S, Bando T, Okano Y, Otani H, Nakshima Y, Wada H. A case of congenital pulmonary vein stenosis in an adult. Respiration 2004; 71:92-94. [PubMed]

24. Tan CW, Munfakh N, Helmcke F, Abourahma A, Caspi J, Glancy DL. Congenital bilateral pulmonary venous stenosis in an adult: diagnosis by echo-Doppler. Catheter Cardiovasc Interv 2000;49:328 -30. [PubMed]

25. Saad EB, Marrouche NF, Saad CP, Ha E, Bash D, White RD, Rhodes J, Prieto L, Martin DO, Saliba WI, Schweikert RA, Natale A. Pulmonary vein stenosis after catheter ablation of atrial fibrillation: emergence of a new clinical syndrome. Ann Intern Med 2003; 138:634-38. Summary for patients in: Ann Intern Med 2003; 138:1. [PubMed]

26. Smallhorn JF, Pauperio H, Benson L, Freedom RM, Rowe RD. Pulsed Doppler assessment of pulmonary vein obstruction. Am Heart J 1985; 110:483- 86. [PubMed]

27. Qureshi AM, Prieto LR, Latson LA, Lane GK, Mesia CI, Radvansky P,White RD, Marrouche NF, Saad EB, Bash DL, Natale A, Rhodes JF. Transcatheter angioplasty for acquired pulmonary vein stenosis after radiofrequency ablation. Circulation 2003; 108:1336 42.

28. Kawashima Y, Ueda T, Naito Y, Morikawa E, Manabe H. Stenosis of Pulmonary Veins: Report of a Patient Corrected Surgically. Ann Thorac Surg 1971; 12:196-202. [PubMed] 
Review Article

29. Lacour-Gayet F, Rey C, Planche C. Pulmonary vein stenosis: description of a suture-less surgical technique using the pericardium in situ. Arch Mal Coeur Vaiss 1996; 89:6336. [PubMed]

30. Yun TJ, Coles JG, Konstantinov IE, Al-Radi OO, Wald RM, Guerra V, de Oliveira NC, Arsdell GS, Williams WG, Smallhorn J, Caldarone CA. Conventional and Suture less techniques for management of the pulmonary veins: evolution of indications from post repair pulmonary vein stenosis to primary pulmonary vein anomalies. J Thorac Surg 2005; 129: 167-74.

31. Azakie A, Lavrsen MJ, Johnson NC, Sapru A. Early Outcomes of Primary Suture less Repair of the Pulmonary Veins. Ann Thorac Surg, 2011; 92:666 -72. [PubMed]

32. Mendeloff EN, Spray TL, Huddleston CB, Bridges ND, Canter CB, Mallory GB Jr. Lungtransplantation for congenital pulmonary vein stenosis. Ann Thorac Surg. 1995;60:903-6.

[PubMed]

33. Sands A, Craig B, Casey F. A possible role for steroid therapy in preventing postoperative stenosis in TAPVC. Cardiol Young 1998; 8:240-2.

34. Rehman M, Jenkins KJ, Juraszek AL, Connor JA, Gauvreau K, Muneeb M, Sena LM, Colan SD, Saia T, Kieran MW. A prospective phase II trial of vinblastine and methotrexate in multi vessel Intra luminal pulmonary vein stenosis in infants and children. Congenit Heart Dis 2011; 6:608-23. doi: 10.1111/j.1747-0803.2011.00574.x. Epub 2011 Nov 11.
35. Bromberg-Marin G, Tsimikas S, Mahmud E. Treatment of Recurrent Pulmonary Vein Stenoses With Endovascular Stenting and Adjuvant Oral Sirolimus. Catheter Cardiovasc Interv 2007; 69:362-368. [PubMed]

36. Balasubramanian S, Marshall AC, Gauvreau K, Peng LF, Nugent AW, Lock JE, McElhinney DB. Outcomes After Stent Implantation for the Treatment of Congenital and Postoperative Pulmonary Vein Stenosis in Children. Circ Cardiovasc Interv. 2012; 5:109-17. [PubMed]

37. Lock JE, Bass JL, Castaneda- Zuniga W, Fuhrman BP, Rashkind WJ, Lucas RV Jr. Dilation angioplasty of congenital or operative narrowings of venous channels. Circulation 1984; 70:457-64. [PubMed]

38. Mendelsohn AN, Bove EL, Lupinetti FM, Crowley DC, Lloyd TR, Fedderly RT. Intra- operative and percutaneous stenting of congenital pulmonary artery and vein stenosis. Circulation 1993; 88: II 210-17. [PubMed]

39. Bingler MA, Darst JR, Fagan TE. Cryo-balloon angioplasty for pulmonary vein stenosis in pediatric patients. Pediatr Cardiol 2012; 33(1):109-14. [PubMed]

40. Mueller GC, Dodge-Khatami A, Weil J. First experience with a new drug-eluting balloon for the treatment of congenital pulmonary vein stenosis in a neonate. Cardiol Young. 2010; 20(4):455-8. [PubMed]

41. McMahon CJ, Mullins CE, El Said HG. Intrastent sonotherapy in pulmonary vein restenosis: a new treatment for a recalcitrant problem. Heart 2003; 89:e6 doi:10.1136/heart.89.2.e6. [PubMed]

\section{How to cite this article?}

Navaneetha Sasikumar, Indra Kuladhipati, Sowmya Ramanan, Premsekar Rajasekaran, Raghavan Suramanyan, Krishna Manohar Soman Rema. Congenital Pulmonary vein stenosis - Diagnosis and treatment. Int J Med Res Rev 2013;1(1):20-26. doi: 10.17511/ijmrr.2013.i01.04. 